Magdalena Wawoczny

Uniwersytet Ekonomiczny w Krakowie

wmagda13@gmail.com

\title{
Wpływ pandemii COVID-19 na zmiany W wielkości ruchu pasażerskiego transportu lotniczego w Polsce i na świecie
}

\section{Streszczenie}

Wybuch pandemii COVID-19 spowodował ograniczenie przemieszczania się ludności na świecie, wskutek czego popyt na usługi transportowe gwałtownie spadł. Lotnictwo cechujące się dynamicznym rozwojem dziś ponosi duże straty, czego wyrazem jest kryzys tej branży. Celem rozdziału jest rozpoznanie wpływu pandemii na zmiany wielkości popytu na usługi lotnicze w Polsce i na świecie. Analiza literatury przedmiotu oraz danych wtórnych pozwoliła na zidentyfikowanie zmian wielkości ruchu pasażerskiego spowodowanych pandemią, ze szczególnym uwzględnieniem rynku chińskiego jako benchmarkingu dla branży lotniczej.

\section{Wprowadzenie}

W obecnych czasach transport lotniczy stał się powszechnie wykorzystywanym środkiem transportu. Postęp techniczno-technologiczny oraz wzrost poziomu zamożności społeczeństw to jedne z wielu czynników, które sprawiły, że latać można wszędzie oraz często przy wykorzystaniu niewielkich nakładów finansowych. Według danych polskiego Urzędu Lotnictwa Cywilnego (2019) w 2019 r. polskie lotniska obsłużyły $49 \mathrm{mln}$ pasażerów, czyli o 7\% więcej niż w roku ubiegłym. Pojawienie się w 2020 r. pandemii COVID-19 sprawiło, że sytuacja branży lotniczej w Polsce i na świecie może niespodziewanie powrócić do stanu sprzed kilku dekad. Celem pracy jest rozpoznanie wpływu pandemii COVID-19 na zmiany wielkości popytu na usługi lotnicze. Szczególne rozważania w tej kwestii odnoszą się do rynku chińskiego jako wzorca przeciwdziałania zaistniałej sytuacji. 
W opracowaniu dokonano przeglądu literatury przedmiotu, a także wykorzystano dane empiryczne pochodzące z publikowanych źródeł wtórnych. Dodatkowo przedstawione zostały prognozy dotyczące sytuacji branży lotniczej w najbliższej przyszłości.

\section{Transport powietrzny w strukturze środków transportu i determinanty jego rozwoju}

Transport jest obszarem gospodarki, który umożliwia swobodne przemieszczanie się osób oraz towarów. Definiuje się go jako celowe przemieszczanie się ładunków i osób, wydzielone $z$ innych czynności ekonomicznie, technicznie oraz organizacyjnie. Oznacza to, że transport związany jest $z$ wykorzystaniem infrastruktury, środków transportu, a także obecnością podmiotów gospodarczych, świadczących usługi transportowe (Koźlak, 2008).

Odgrywa on istotną rolę, gdyż umożliwia funkcjonowanie innych sektorów gospodarki i przyczynia się do rozwoju gospodarczego. Pełni funkcję wymiany dóbr i usług, lokalizacji osadnictwa i produkcji, czynnika wzrostu PKB oraz instrumentu zaspokajającego potrzeby transportowe ludności (Grzywacz, Burnewicz, 1989).

Powszechnie stosowaną klasyfikacją transportu jest podział ze względu na środowisko, w którym porusza się dany środek transportu. Wyróżnia się zatem transport lądowy, wodny oraz powietrzny. W następstwie należy przytoczyć podział ze względu na środek transportu, w którym wymienia się transport samochodowy, kolejowy, morski oraz lotniczy (Page, 2005).

Transport lotniczy, z uwagi na przewóz pasażerów, rozwija się najszybciej z pozostałych rodzajów transportu. Cechuje go możliwość szybkiego przemieszczania się na długich dystansach, duży zasięg przestrzenny dzięki lokalizacji terminali lotniczych, komfort oraz najwyższy wskaźnik bezpieczeństwa. Do negatywnych cech należy zaliczyć dojazd do terminali lotniskowych i wysoki koszt przemieszczania się (Urbanyi-Popiołek, 2013).

Przedmiotem przejazdów lotniczych są ładunki pocztowe i towarowe, a przede wszystkim pasażerowie, na których przypada $70 \%$ pracy przewozowej lotnictwa. Przejazdy następują na relacjach krajowych lub międzynarodowych, o zasięgu międzykontynentalnym, średnim lub krótkim. Jeśli chodzi o przejazdy międzykontynentalne, lotnictwo jest monopolistą na rynku ze względu na czas przeprawy (Urbanyi-Popiołek, 2013).

Podaż $\mathrm{w}$ transporcie lotniczym reprezentowana jest przez porty lotnicze oraz przewoźników tradycyjnych i niskokosztowych. Przewoźnicy tradycyjni to przedsiębiorstwa powstałe $z$ inicjatywy konkretnych państw, oferujące regularne połączenia na wybranych trasach. W cenę biletu często wliczone są udogodnienia, takie jak bagaż o określonej wadze czy posiłki. Przewoźnicy niskokosztowi z kolei oferują przejazdy po niższych cenach, jednak udogodnienia są dodatkowo płatne. Przedstawiciele strony popytowej na usługi lotnicze to pasażerowie grupowi lub 
indywidualni, firmy oraz pośrednicy. Popyt charakteryzuje się wahaniami i sezonowością, a także brakiem elastyczności względem ceny (Rucińska i in., 2010).

Postęp technologiczny oraz zmiany w strukturach gospodarczych krajów na przestrzeni lat wpłynęły na rozwój w wielu obszarach gospodarki, także transportu lotniczego. Do determinant jego rozwoju zalicza się m.in. czynniki techniczne. Dzięki rozwojowi Internetu i urządzeń technicznych poprawił się komfort planowania i odbywania przejazdu. Warto wspomnieć o czynnikach politycznych, przez które rozumie się inwestycje państw w rozwój infrastruktury lotniczej oraz prowadzenie przyjaznej polityki zagranicznej, dzięki której możliwe jest tworzenie siatek połączeń międzynarodowych. Na rozwój lotnictwa mają wpływ także czynniki społeczne, powodujące zmiany w odczuwanych potrzebach ludzi, będące skutkiem wzrostu poziomu edukacji czy normalizacji czasu pracy. Ponadto czynniki ekonomiczne, czyli korzystna koniunktura gospodarczo-społeczna lub wzrost dochodów ludności i ich odpowiedni podział, również stymulują rozwój transportu lotniczego (Kaczmarska, 2014). Niestety istnieją też czynniki, które oddziałują negatywnie na rozwój lotnictwa lub całkowicie go hamują. Konflikty polityczne, ataki terrorystyczne czy kryzysy gospodarcze to tylko niektóre destymulanty, niosące pejoratywne skutki dla rozwoju branży lotniczej. W ostatnim czasie czynnikiem determinującym sytuację transportu powietrznego na świecie jest pandemia, będąca następstwem masowego przemieszczania się ludności.

\section{Rola transportu lotniczego $\mathrm{w}$ rozwoju turystyki}

Powszechnie wiadomo, że związek transportu z turystyką jest nierozerwalny. Jako jeden $z$ bazowych elementów infrastruktury turystycznej jest spoiwem pomiędzy miejscem stałego przebywania a destynacją turystyczną. Turystyka nie tylko zależy od transportu, ale także stwarza warunki jego rozwoju i oddziałuje na niego. Oprócz zapewnienia turystom połączenia komunikacyjnego do punktu docelowego baza transportowa gwarantuje swobodne poruszanie się w miejscu recepcji turystycznej oraz dostęp do jej walorów turystycznych (Gross, Klemmer 2014).

O ile każdy rodzaj transportu odgrywa ważną rolę na rynku turystycznym, o tyle duży wpływ lotnictwa na rozwój ruchu turystycznego w ostatnich latach jest niezaprzeczalny. Transport lotniczy winno określać się mianem fundamentu globalizacji, bowiem dyktuje on procesy globalizacyjne, tym samym im podlegając. Należy zatem stwierdzić, że przemysł turystyczny nie może istnieć bez usług lotniczych. Według danych IATA (2019) w 2019 r. współczynnik obłożenia pasażerów wzrósł o ponad 3,4\%, czyniąc jednocześnie ten wynik nowym rekordem. Ponadto turyści korzystający z usług lotniczych przeznaczyli na nie ponad 900 mld dolarów. Można zatem zaryzykować stwierdzenie, że transport lotniczy jest jednym z najchętniej i najczęściej wybieranych środków transportu.

Korzyści, jakie stwarza dla turystyki transport lotniczy, to przede wszystkim spadek kosztów transportu pasażerów. Tani przewoźnicy, oferujący przeloty w niskich cenach, uczynili podróżowanie bardziej dostępnym, kwalifikując turystykę do dóbr podstawowych. Dodatkowo efektywność transportu lotniczego ma 
bezpośredni wpływ na sytuację społeczno-gospodarczą w wielu krajach. Działanie aktywnych portów lotniczych w regionach zwiększa jego konkurencyjność oraz wspiera gospodarkę. Oprócz przypływu turystów należy zaznaczyć, że umożliwia on przepływ wszelkiego rodzaju towarów, powodując rozwój nowoczesnych gałęzi przemysłu (Nedeva, Genchev, 2018).

Stale rosnący popyt na usługi lotnicze i prognozy dotyczące jego systematycznego wzrostu zobligowały linie oraz porty lotnicze do poszerzania siatki i częstotliwości połączeń, zgodnie $z$ trendami i potrzebami rynku.

\section{Rozwój turystyki w Polsce i na świecie do roku 2019 - wybrane aspekty}

W ostatnich dekadach można było zaobserwować rozwój międzynarodowego ruchu turystycznego. Od 1995 r. wzrastał on co roku w tempie 4\% w skali światowej. Stabilny w czasie rozwój turystyki był możliwy dzięki zwiększeniu się funduszu swobodnej decyzji ludności na świecie, który zaczęto przeznaczać na konsumpcję turystyczną. Dynamika jej rozwoju sprawiła, że wiele krajów, inwestując w turystykę, uczyniło z niej główny czynnik rozwoju społeczno-ekonomicznego (Polski Instytut Ekonomiczny, 2020). W 2015 r. liczba podróży międzynarodowych wynosiła $1186 \mathrm{mln}$, a łączne wydatki na turystykę sięgały nawet 1260 mld dolarów. Zaledwie cztery lata później, w 2019 r., liczba podróży zwiększyła się do 1,4 mld, czyli o 4\% w porównaniu do 2018 r., natomiast suma wydatków turystycznych wzrosła do 1,7 tryliona (UNWTO, 2016-2020).

Również w Polsce odnotowano tendencje wzrostowe, dotyczące oddziaływania turystyki na gospodarkę krajową. Łączne wpływy z zagranicznej turystyki do Polski wynosiły w 2019 r. 29 mld zł, czyli wzrosły o 3,3\% w porównaniu do roku poprzedniego. Wydatki turystyczne Polaków w kraju w 2019 r. były większe o ponad $11 \%$ od tych w 2018 r. i wynosiły 11 mld zł. Polacy chętniej niż w poprzednich latach podejmowali podróże krajowe i zagraniczne. W 2019 r. zanotowano 20,6 mln podróży krajowych (wzrost o 5,1\% do roku ubiegłego) oraz 5,7 mln podróży zagranicznych, czyli o 5,7\% więcej niż w roku 2018 (Ministerstwo Sportu i Turystyki, 2019).

Jeśli chodzi o turystykę międzynarodową, państwem, do którego od lat najchętniej przyjeżdżają turyści, jest Francja. Drugie miejsce, do 2017 r., zajmowały Stany Zjednoczone, jednak rok później USA spadły o poziom niżej w rankingu, ustępując miejsca Hiszpanii. W latach 2016-2019 wśród krajów mających największe wpływy z turystyki znalazły się Stany Zjednoczone, Chiny, Hiszpania oraz Tajlandia. Warto również zaznaczyć, że krajem, którego mieszkańcy wydają najwięcej na turystykę, są Chiny, a zaraz po nich Hiszpania, Tajlandia oraz Francja (UNWTO, 2016-2020).

Jeśli chodzi o sytuację światowego rynku lotniczego w ostatnich dekadach, latanie stało się bardziej dostępne niż kiedykolwiek. Biorąc pod uwagę liczbę obsłużonych podróżujących, liderami na rynku światowym są kolejno Southwest 
Airlines, Delta Airlines, American Airlines oraz Ryanair. Z kolei w Polsce najchętniej wybieranymi liniami okazały się Ryanair oraz Lot. W 2019 r. polskie lotniska pobiły rekord, obsługując prawie $49 \mathrm{mln}$ pasażerów, czyli o $7 \%$ więcej niż w roku poprzednim (IATA, 2019).

Pomimo występowania w przeszłości zdarzeń kryzysowych i chwilowych spadków wielkości ruchu pasażerskiego branża lotnicza odnotowywała jego wzrost do 2020 r. na poziomie 4,5 mln pasażerów (ryc. 1). Wirus Sars-CoV-2, powodujący pandemię COVID-19, zapoczątkował szereg poważnych zmian najpierw w samych Chinach. Chiny bowiem od lat zajmowały czołowe miejsce wśród krajów generujących największą liczbę turystów. Pojawienie się zatem nowego wirusa, który zmusił chiński rząd do izolacji obywateli, spowodował spadek popytu na usługi lotnicze, czego skutki stopniowo zaczynały odczuwać pozostałe kraje, do których wcześniej masowo latali Chińczycy. Początek roku 2020 to czas rozprzestrzeniania się wirusa na obszar całego świata, co niosło szereg negatywnych dla branży lotniczej skutków, które wymagać będą opracowania nowych rozwiązań.

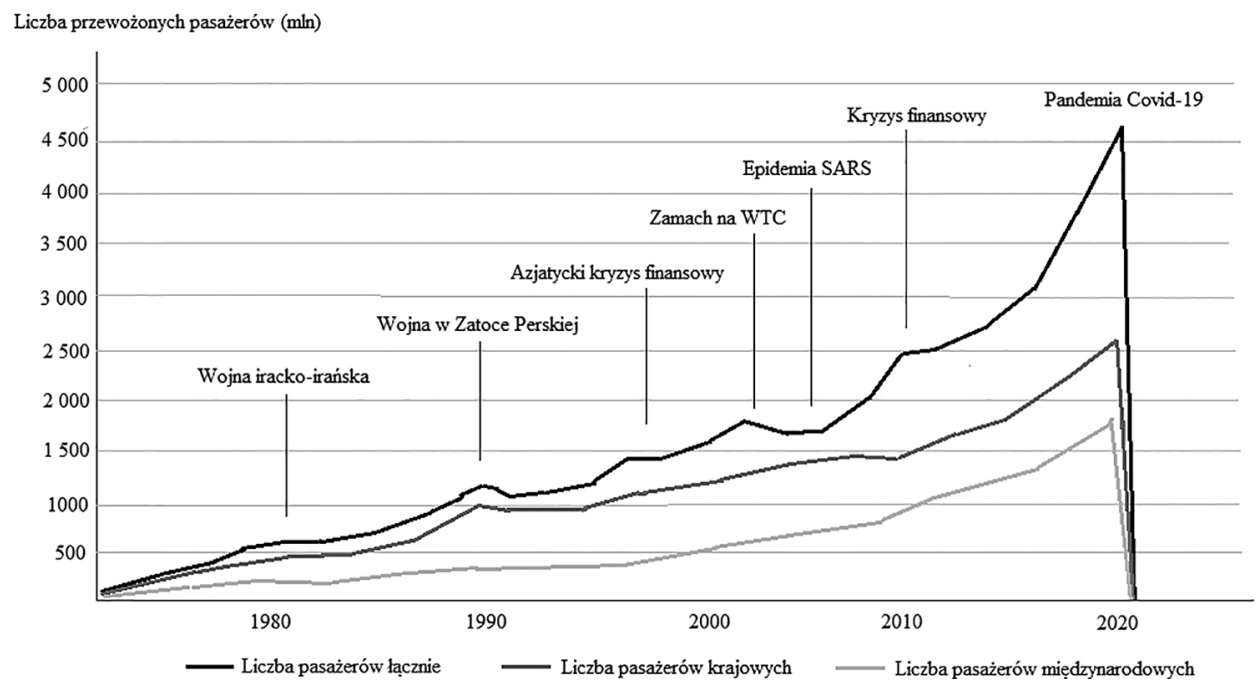

Ryc. 1. Ewolucja światowego ruchu pasażerskiego do roku 2020

Źródło: opracowanie własne na podstawie danych pochodzących z panelu „Quo Vadis Turystyko?” w ramach 12 Międzynarodowej Konferencji Naukowej Kolegium Nauk o Zarządzaniu i Jakości Uniwersytetu Ekonomicznego w Krakowie.

\section{Ruch pasażerski w czasie pandemii COVID-19}

W ostatnich latach na podstawie danych statystycznych przedstawiających coroczny wzrost poziomu ruchu pasażerskiego oszacowano, że w 2020 r. obsłużonych zostanie ponad 9 mld pasażerów na świecie. Pojawienie się nowego wirusa pod koniec 2019 r. spowodowało obniżenie się dotychczasowego poziomu ruchu o ponad 5,5 mld. 
Nigdy wcześniej branża lotnicza nie zanotowała tak nagłego spadku poziomu ruchu. Pomimo chwilowych regresji, wywołanych konkretną bariera, ruch ten szybko się ożywiał. Pandemia COVID-19, która początkowo zapowiadała kryzys obejmujący swoim zasięgiem jedynie Chiny i kraje ościenne, spowodowała powrót pasażerskiego ruchu lotniczego do poziomu sprzed kilkudziesięciu lat. Zjawisko to przedstawiono na rycinie 2, na której spadek światowego ruchu pasażerskiego zobrazowany został na podstawie wskaźnika RPK, pokazującego przychody przewoźnika lotniczego, przeliczane na jeden pasażero-kilometr.

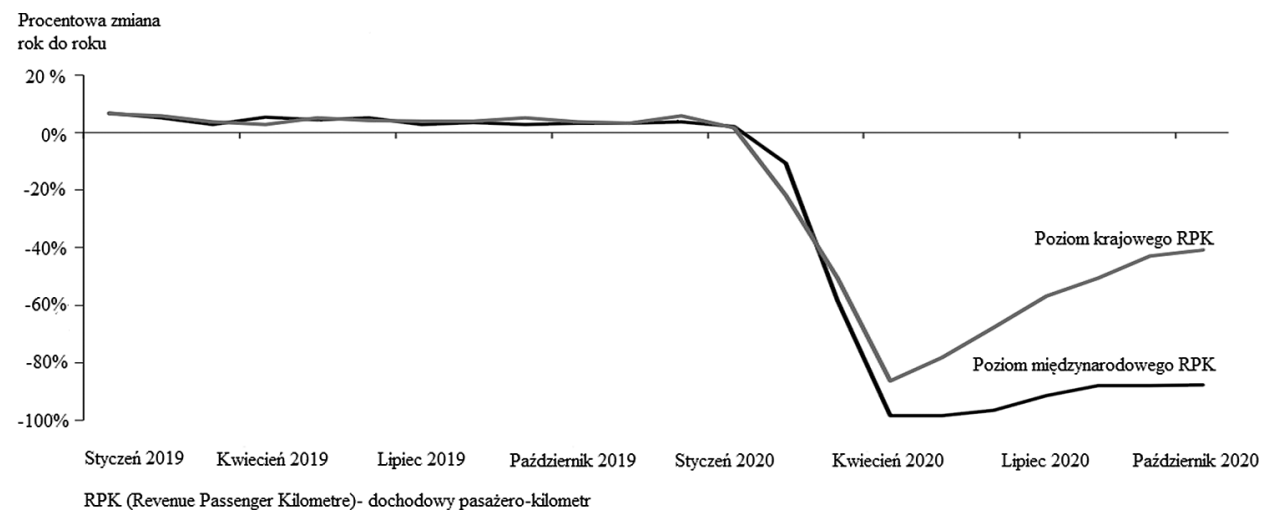

Ryc. 2. Spadek lotniczego ruchu pasażerskiego na świecie na przykładzie RPK Źródło: opracowanie własne na podstawie IATA Statistics.

Sytuację na rynku polskim odzwierciedla rycina 3, na której porównano ruch pasażerski na lotnisku w Balicach w latach 2019-2020 od stycznia do października. Pomimo dobrze zapowiadającego się początku roku, wybuch pandemii w Europie ograniczył ten ruch do zera. Stopniowe luzowanie obostrzeń pozwoliło w następnych miesiącach na przywrócenie jedynie $37 \%$ ruchu z poprzedniego roku. Największy udział w odbudowie przypadł tanim przewoźnikom, którzy przywrócili $46 \%$ operacji od lipca do października, a przewoźnicy tradycyjni $41 \%$.

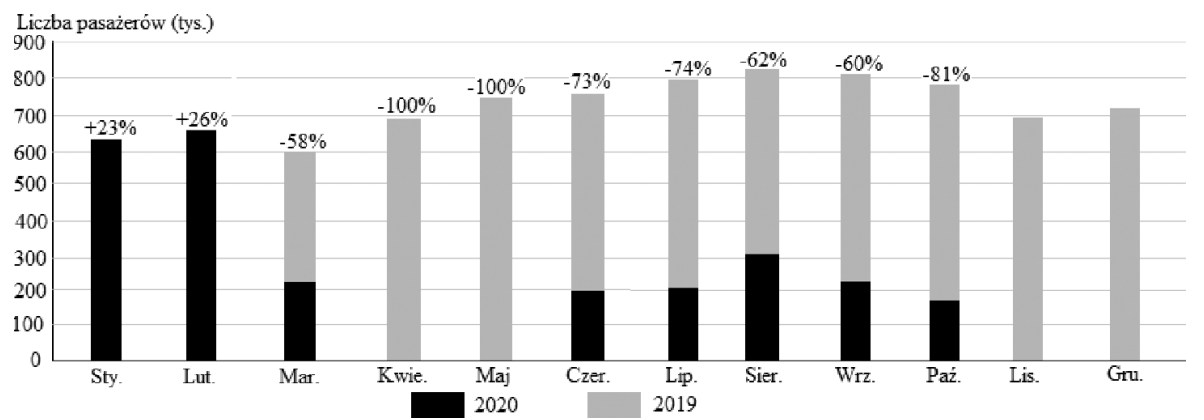

Ryc. 3. Poziom ruchu pasażerskiego krakowskiego lotniska w 2020 r. na tle poziomu z 2019 r. (styczeń-wrzesień)

Źródło: opracowanie własne na podstawie danych pochodzących z panelu „Quo Vadis Turystyko?” w ramach 12 Międzynarodowej Konferencji Naukowej Kolegium Nauk o Zarządzaniu i Jakości Uniwersytetu Ekonomicznego w Krakowie. 
Chiny były pierwszym krajem zmagającym się z pandemią, również pierwszym, który zaczął podejmować działania w celu ożywienia rynku transportu lotniczego. W przeciwnej sytuacji znalazła się pozostała część świata, która odnotowywała w tym czasie gwałtowne wzrosty zakażeń. Sukces stopniowego wyjścia Chin z kryzysu widać na tle porównania danych, przedstawiających stosunek dziennej liczby zakażeń do liczby dziennych lotów krajowych i międzynarodowych w Chinach, Europie i USA, ukazanych na rycinach 4 i 5.

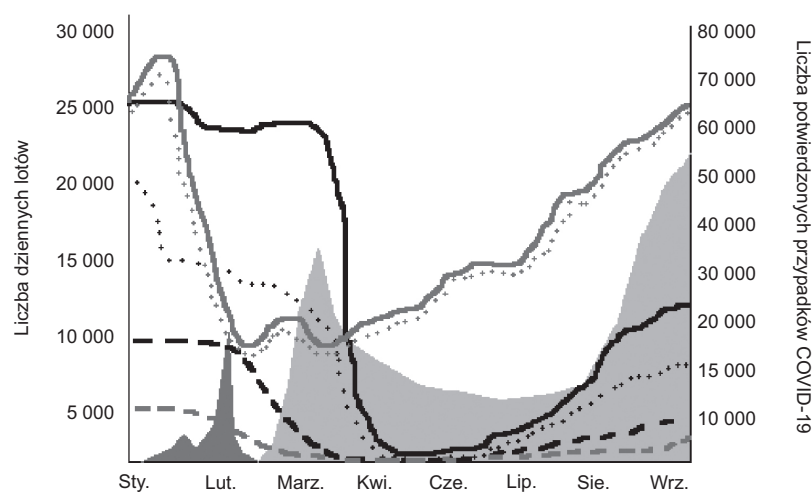

$\square$ Liczba dziennych zakażeń w Europie $\quad \square$ Liczba dziennych zakażeń w Chinach

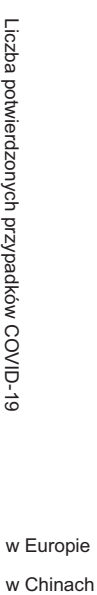

Ryc. 4. Dzienne loty i potwierdzone przypadki w pierwszej połowie $2020 \mathrm{r}$. w Chinach

i Europie

Źródło: opracowanie własne na podstawie danych ADS- B, Flightradar24 i Europejskiego Centrum ds. Zapobiegania i Kontroli Chorób.

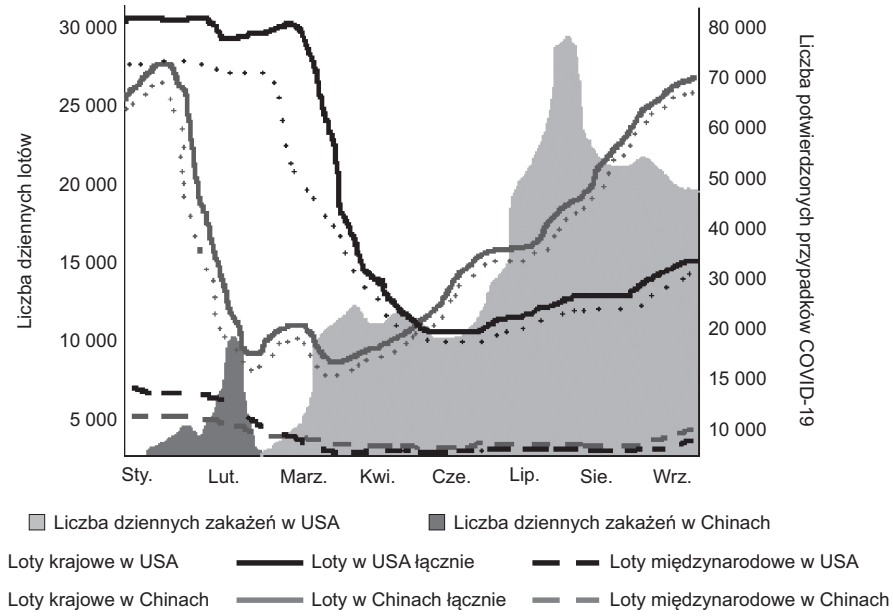

Ryc. 5. Dzienne loty i potwierdzone przypadki w pierwszej połowie $2020 \mathrm{r}$. w Chinach i w USA

Źródło: opracowanie własne na podstawie danych ADS-B, Flightradar24 i Europejskiego Centrum ds. Zapobiegania i Kontroli Chorób. 
W momencie wprowadzenia w krajach europejskich nakazu izolacji popyt na usługi lotnicze spadł, a ruch pasażerski został wstrzymany. Odwrotnie rzecz miała się na rynku chińskim, gdzie w tym czasie odnotowywano wzrost popytu na krajowe usługi lotnicze oraz brak nowych przypadków zakażeń. W Europie zmiana nastąpiła dopiero na początku czerwca, kiedy popyt zaczął rosnąć przy jednoczesnym spadku liczby nowych zakażeń. Co ciekawe, tendencja ta utrzymywała się w sezonie wakacyjnym pomimo ponownego wzrostu zachorowań. Podobnie jak w przypadku Europy, USA również odnotowały znaczny spadek liczby dziennych lotów krajowych, który utrzymywał się do czasu względnego spadku poziomu zachorowań. Co ciekawe, odmiennie niż w Europie, wbrew ponownemu wzrostowi dziennych zakażeń w USA liczba dziennych lotów utrzymuje się na względnie stałym poziomie, momentami nawet wzrastając.

Według analiz dokonanych przez serwis Flightradar24 (2020), pomyślność chińskiej branży lotniczej w stopniowym przywracaniu ruchu pasażerskiego zależała od wprowadzenia trzech faz ożywienia (ryc. 6). W fazie I, po gwałtownym spadku zachorowań, chińskie linie lotnicze przywróciły loty krajowe, na które popyt wzrósł natychmiast. Jednocześnie ruch międzynarodowy w dalszym ciągu pozostawał stłumiony ze względu na panujące obostrzenia. W fazie II, przypadającej na kwiecień 2020 r., zniesione zostały restrykcje dotyczące nakazu kwarantanny w Chinach. Popyt na loty krajowe w dalszym ciągu wzrastał miesięcznie średnio o $10 \%$, co w maju pozwoliło osiągnąć poziom liczby lotów krajowych sprzed

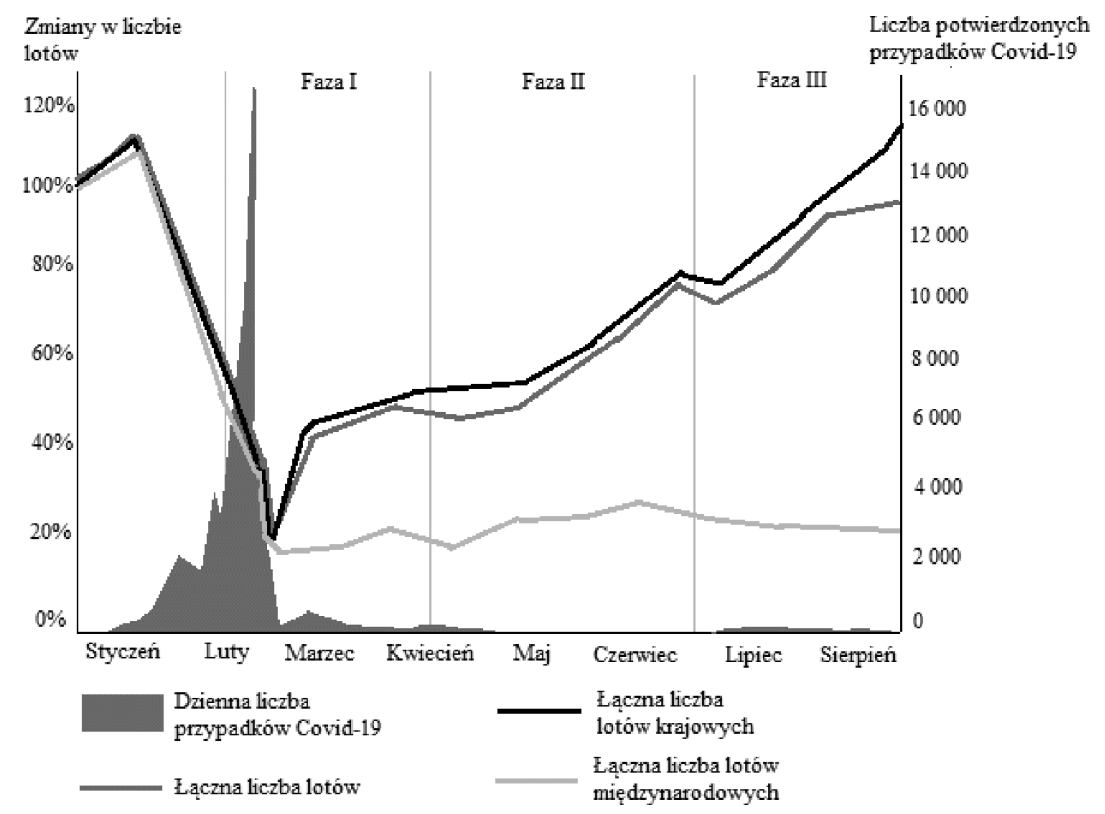

Ryc. 6. Zmiany w krajowych i międzynarodowych dziennych lotach w Chinach w 2020 r. (styczeń-sierpień)

Źródło: opracowanie własne na podstawie danych ADS-B, Flightradar24 i Europejskiego Centrum ds. Zapobiegania i kontroli Chorób. 
pandemii. W tym czasie zaobserwowano też powolny wzrost liczby lotów międzynarodowych, które z kolei szybko zostały zniesione wskutek pojawienia się znikomej liczby nowych zakażeń. Jednak natychmiastowa reakcja Chin i szybkie wprowadzenie ponownych ograniczeń pozwoliły na stłumienie nowych ognisk wirusa. Dzięki owym ograniczeniom w III fazie nastąpiło ponowne przywrócenie lotów krajowych i ciągły wzrost poziomu ruchu pasażerskiego. Według analiz do uzyskania takiego wyniku przyczyniły się masowe obniżki cen biletów i wzrost udziału tanich przewoźników (Flightradar24, 2020).

Analizując sytuację Europy, USA oraz Chin, można zauważyć, że żadne z nich nie odnotowało znaczącego wzrostu popytu i ruchu pasażerskiego w odniesieniu do lotów międzynarodowych. Dzieje się tak ze względu na zależność dostosowania siatki lotów międzykontynentalnych do sytuacji epidemicznej każdego państwa. Strategia Chin, dotycząca lotów na trasach międzynarodowych, miała charakter restrykcyjny. Od 12 marca 2020 r. każdej chińskiej linii lotniczej zezwolono na zrealizowanie jednego lotu tygodniowo do każdego państwa znajdującego się w jej siatce połączeń. Z kolei każda zagraniczna linia lotnicza uzyskała pozwolenie na obsłużenie jednej trasy do Chin tygodniowo, z obłożeniem pasażerów nie większym niż $75 \%$. Warunki te obowiązywały do momentu zamknięcia granicy chińskiej w dniu 27 marca (Flightradar24, 2020). Można przypuszczać, że szybkie podjęcie działań naprawczych przez Chiny było możliwe dzięki współpracy rządu i linii lotniczych oraz ich natychmiastowej reakcji na ponowne wzrosty zachorowań. Dodatkowo aspektem, który mógł ułatwić wdrażanie w życie działań naprawczych, jest mentalność i specyfika społeczeństwa chińskiego, a także jego stosunek do przestrzegania zaleceń wydawanych przez władze.

\section{Zakończenie}

Stopniowy powrót do realizacji liczby lotów krajowych sprzed pandemii ułatwiło powstanie wymuszonego trendu na turystykę krajową. Nawroty ognisk wirusa w sezonie zimowym i wzrosty zakażeń powodują wahania i uniemożliwiają opracowanie długoterminowych prognoz. Obecnie lotnictwo nie znajduje się $\mathrm{w}$ sytuacji, w której pandemia została opanowana, a testowanie pasażerów przed każdorazową podróżą jest rozwiązaniem chwilowym, kosztownym i ograniczającym popyt.

Transport lotniczy, który obsługuje $60 \%$ wszystkich podróżujących na świecie, może spodziewać się ponownego wzrostu popytu, jeśli wprowadzone zostaną odpowiednie procedury gwarantujące bezpieczeństwo. Na pytanie, kiedy branża wróci do sytuacji sprzed pandemii, istnieje, jak się wydaje, tylko jedna odpowiedź, a mianowicie wdrożenie szczepionki. Można zaryzykować stwierdzenie, że w przyszłości jedynie zaszczepieni pasażerowie będą mogli korzystać z usług lotniczych nie tylko na trasach międzynarodowych, ale i krajowych, a szczepionka stanie się przepustką do podróżowania. Za przykład poparcia tej tezy może posłużyć spot reklamowy linii Ryanair, który zachęca do kupna tanich biletów hasłem „zaszczep się i leć”. 
Branża transportu lotniczego niejednokrotnie pokazała, jak duże znaczenie ma dla światowej gospodarki. Lotnictwo zdolne do pokonania takich barier, jak recesje czy konflikty militarne, będzie w stanie poradzić sobie z kryzysem, jakim jest pandemia COVID-19. Oprócz szczepień wzrostowi popytu sprzyjają prognozy dotyczące cen biletów. Największy udział w rynku europejskim mają obecnie tanie linie, oferujące niskie taryfy. Duża ilość tanich biletów oraz szeroka siatka połączeń siłą rzeczy wymusi walkę konkurencyjną między tanimi a tradycyjnymi liniami lotniczymi, co może skutkować spadkiem cen przelotów linii tradycyjnych.

W wariancie optymistycznym do wygaszenia pandemii może dojść w sezonie letnim 2021 r. W dłuższej perspektywie pandemia COVID-19 tylko przyspieszyła procesy, których realizacja normalnie trwałaby latami. Zmuszają one zatem przedstawicieli nie tylko branży lotniczej do analizy negatywnego wpływu procesów globalnych i masowego przemieszczania się, a także do wprowadzenia rozwiązań zgodnych z ideą zrównoważonego rozwoju.

\section{Literatura}

Flightradar24 (2020). Can we learn from China's traffic recovery? (www.flightradar24. com; dostęp: 20.12.2020).

Gross S., Klemmer L. (2013). Introduction to tourism transport. Hochschule Harz - University of Applied Sciences, Berlin.

Grzywacz W., Burnewicz J. (1989). Ekonomika transportu. WKiŁ, Warszawa.

IATA (2019). In numbers: World Air Transport Statistics (www.airlines.iata.org; dostęp: 9.01.2020).

Kaczmarska A. (2014). Wybrane czynniki rozwoju turystyki. Studia Ekonomiczne, 176(14): 201-215.

Koźlak A. (2008). Ekonomika transportu. Teoria i praktyka gospodarcza. WUG, Gdańsk.

Ministerstwo Sportu i Turystyki (2019). Podstawowe dane statystyczne z turystyki za I półrocze 2019 (www.msit.gov.pl; dostęp: 9.01.2020).

Nedeva K., Genchev E. (2018). Air Transport - a source of competitive advantages of the region. Marketing and Branding Research, 5: 206-216.

Page S. (2005). Transport and tourism. Global Perspectives. Pearson Prentice Hall, Edinburgh.

Polski Instytut Ekonomiczny (2020). Branża turystyczna w Polsce. Obraz sprzed pandemii. Warszawa.

Rucińska D., Ruciński A., Tłoczyński D. (2010). Transport lotniczy - ekonomika i organizacja. WUG, Gdańsk.

UNWTO (2016-2019). Tourism Highlights 2016-2019 Editions (www.unwto.org; dostęp: 9.01.2020).

Urbanyi-Popiołek I. (red.) (2013). Ekonomiczne i organizacyjne aspekty transportu. Wydawnictwo Uczelniane WSG, Bydgoszcz.

Urząd Lotnictwa Cywilnego (2020). Przewozy pasażerskie w transporcie lotniczym w 2019 r. (www.ulc.gov.pl; dostęp: 25.12.2020). 


\section{The impact of COVID-19 pandemic on changes in the volume of passenger air traffic in Poland and in the world}

The outbreak of COVID-19 pandemic caused the restriction on the movement of people around the world, as a result of which the demand for transport services instantly fell down. Aviation, which is characterized by dynamic development, today suffers from large losses, which is reflected in the crisis of this industry. The aim of the article is to identify the impact of the pandemic on changes in the demand for air services in Poland and around the world. The analysis of the literature and secondary data allowed to identify changes in the volume of the passenger traffic caused by the pandemic, with particular emphasis on the chinese market as a benchmarking for the aviation industry.

Translated by Magdalena Wawoczny 